$L A-13293-P R$

Progress Report



\section{RECEIVED \\ NOV 021998 \\ O OTI}

\section{Advanced Recovery and Integrated \\ Extraction System (ARIES)}

Fiscal Year 1996 Annual Report

\section{Los Alamos}

NATIONAL LABORATORY

Los Alamos National Laboratory is operated by the University of California for the United States Department of Energy under contract W-7405-ENG-36. 
Edited by Margaret Burgess, Group CIC-1.

Photocomposition by Wendy Burditt, Group CIC-1;

Barbara Ritchie, Group CIC-1.

This work was supported by the US Department of Energy, Office of Fissile Materials Disposition.

An Affirmative Action/Equal Opportunity Employer

This report was prepared as an account of work sponsored by an agency of the United States Government. Neither The Regents of the University of California, the United States Gotermment nor any agency thercof, nor any of their employees, makes any zarranty, express or implied, or assumes any legal liability or responsibility for the accuracy, completeness, or usefulness of any information, apparatus, product, or process disclosed, or represents that its use would not infringe privately owned rights. Referencc herein to any specific commercial product, process, or service by trade name, trademark, manufacturer, or otherwise, does not necessarily constitute or imply its entorsentent, recommendation, or favoring by The Regents of the University of California, the United States Government, or any agency thereof. The views and opinions of authors expressed hercin do not necessarily state or reflect those of The Regents of the University of California, the United States Government, or any agency thereof. Los Alamos National Laboratory strongly supports academic freedom and a researciter's right to publish; as an institution, however, the Laboratory does not entorse the viewpoint of a publication or guarantee its technical correctness. 


\section{DISCLAIMER}

Portions of this document may be illegible electronic image products. Images are produced from the best available original document. 
Advanced Recovery and Integrated

Extraction System (ARIES)

Fiscal Year 1996 Annual Report

Timothy O. Nelson

Pamela W. Massey

David Dennison*

*Lawrence Livermore National Laboratory Liaison to Group NMT-6.

\section{Los Alamos \\ NATIONAL LABORATORY \\ Los Alamos, New Mexico 87545}





\section{TABLE OF CONTENTS}

ABSTRACT

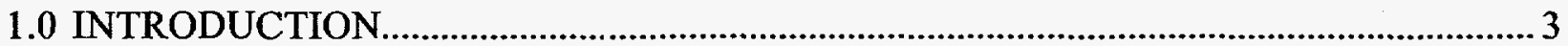

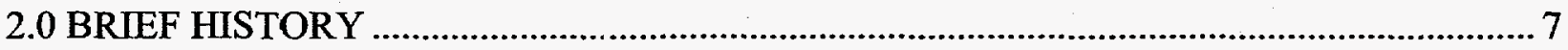

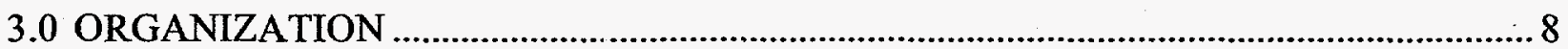

4.0 ARIES DEMONSTRATION PROJECT ACCOMPLISHMENTS DURING THE FIRST YEAR, FY96

4.1 Pit Bisection Module

4.2 Hydride-Dehydride Recycle Module ......................................................................... 10

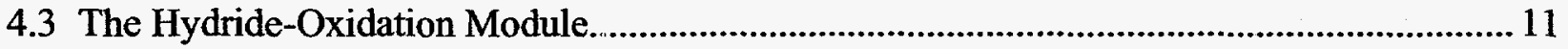

4.4 The Canning Module and Electrolytic Decontamination Module............................................. 13

4.5 Nondestructive Assay System/Robotic Automation Module ................................................. 18

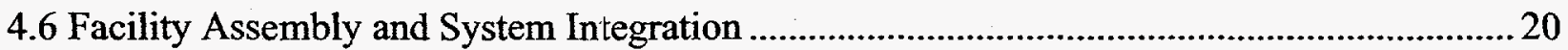

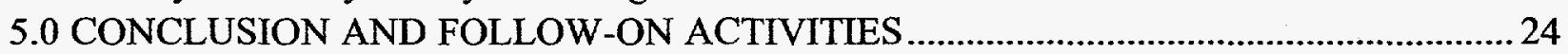

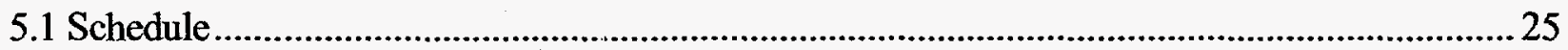

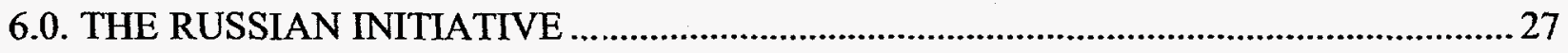

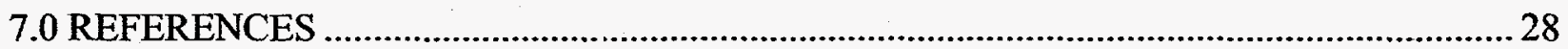




\title{
Advanced Recovery and Integrated Extraction System (ARIES) Fiscal Year 1996 Annual Report \\ by
}

Timothy O. Nelsonı, Pamela W. Massey, and David Dennison

\begin{abstract}
President Clinton issued a Nonproliferation and Export Control Policy in September 1993 in response to the growing threat of nuclear proliferation. Four months later, in January 1994, President Clinton and Russia's President Yeltsin issued a Joint Statement Between the United States and Russia on Nonproliferation of Weapons of Mass Destruction and the Means of Their Delivery. President Clinton announced on 1 March 1995, that approximately 200 metric tons of USorigin weapons-usable fissile materials had been declared surplus to US defense needs. The Advanced Recovery and Integrated Extraction System (ARIES) Demonstration Project is one part of the scientific response to President Clinton's promise to reduce the nuclear weapons stockpile. The work accomplished on the ARIES Demonstration Project during fiscal year 1996, 1 October 1995 through 30 September 1996, is described in this report.

The Department of Energy (DOE), by forming the Office of Fissile Materials Disposition (OFMD), has initiated a Fissile Materials Disposition Program. The first step is the disassembly and conversion of weapons pits. Of the 200 metric tons of US surplus fissile material, approximately 50 tons are weapons plutonium, and of these 50 tons, $2 / 3$ is contained in pits. Weapons plutonium will be extracted from pits, rendered to an unclassified form, and converted to oxide. The plutonium oxide will then be dispositioned either by immobilization in a ceramic matrix or blended with uranium oxide, fabricated into ceramic pellets of mixed oxide (MOX) fuel, and "burned" in a commercial light water reactor.

The purpose of ARIES is to demonstrate two major activities: (1) dismantlement of nuclear weapons, and (2) conversion of weapons-grade plutonium into a form required for long-term storage or in preparation for the disposition (immobilization or MOX fuel) that allows for international inspection and verification, and in accordance with safeguards regimes. Plutonium does not have to be declassified before storage; however, declassification allows plutonium to be placed under international safeguards and provides political irreversibility of the material.
\end{abstract}


The OFMD sponsors the ARIES Program. The Los Alamos National Laboratory is the lead laboratory for the ARIES Demonstration Project with support from Lawrence Livermore National Laboratory and Sandia National Laboratories, New Mexico. Also, ARIES is the lead technical activity for national plutonium disposition, as well as a major effort of the Los Alamos Nuclear Materials Disposition Project. The ARIES Project Leader, Timothy O. Nelson, is a technical staff member in the Advanced Technology Group (NMT-6) who is responsible for overall project management and system implementation. 


\subsection{INTRODUCTION}

The Advanced Recovery and Integrated Extraction System (ARIES) Demonstration Project is an overall processing system for the dismantlement and disposition of nuclear weapons pits, also known as nuclear weapons cores. The project will receive weapons pits, disassemble them, retrieve the plutonium components, convert the plutonium metal into an unclassified product of either a plutonium metal ingot or plutonium oxide powder, and package the product to meet all requirements for long-term storage per the Department of Energy (DOE) standard DOE-STD$3013-96,{ }^{1}$ future disposition paths, and international inspection. The pit conversion process is illustrated in Fig. 1.

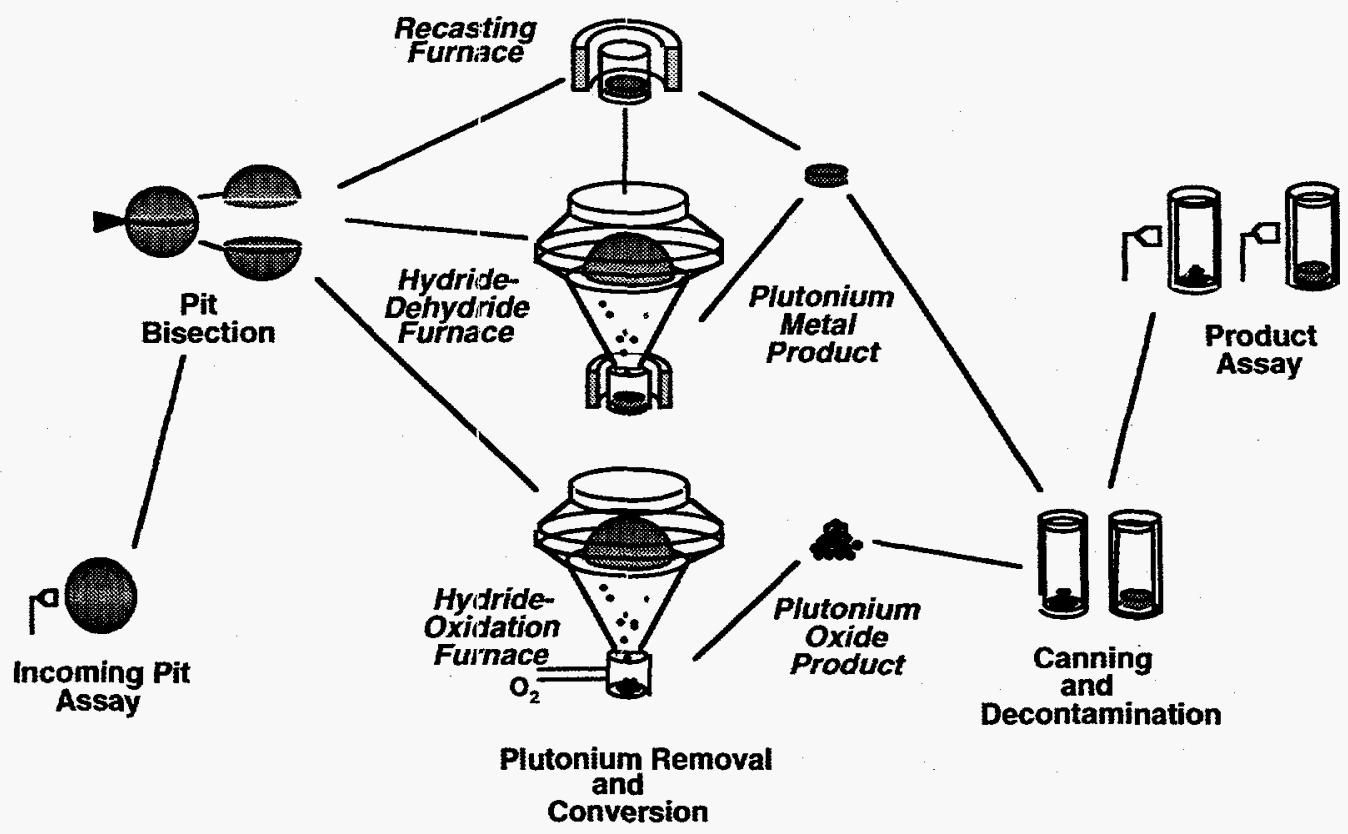

Fig. 1. The ARIES pit conversion process.

ARIES development has resulted in seven module tasks. This modularity offers credible scaling, the flexibility to incorporate modifications or new concepts, and the potential to explore future transport and export capabilities. The modular elements are described below: 
- A Pit Bisection module is used to cut open and physically separate the various components of the weapon pits. This module also includes an advanced parting lathe.

- A Hydride-Dehydride Recycle module is used to remove the plutonium from the weapon component substrate surfaces and cast the plutonium into a metal ingot, as shown in Fig. 2.

- $\quad$ A parallel Hydride-Oxidation (HYDOX) module processes the plutonium following extraction to produce plutonium oxide powder.

- A Canning module produces a double-containment, hermetically sealed storage package of either the plutonium metal ingot or plutonium oxide powder that can be inspected by international agencies. During canning the material is packaged in airtight cans compatible with materials disposition long-term storage requirements.

- The loaded, sealed, and leak-tested inner material cans will then be sent to the Electrolytic Decontamination module to decontaminate the outside surfaces of the cans before removal from the glovebox environment. The inner material can is placed in the second (outer) can, resulting in a DOE-STD-3013-96 ${ }^{1}$ storage container, also shown in Fig. 2.

- A Nondestructive Assay (NDA)/Robotic Automation module is used to analyze the sealed storage cans for material control and accountability of all the special nuclear material and waste items processed by ARIES. 


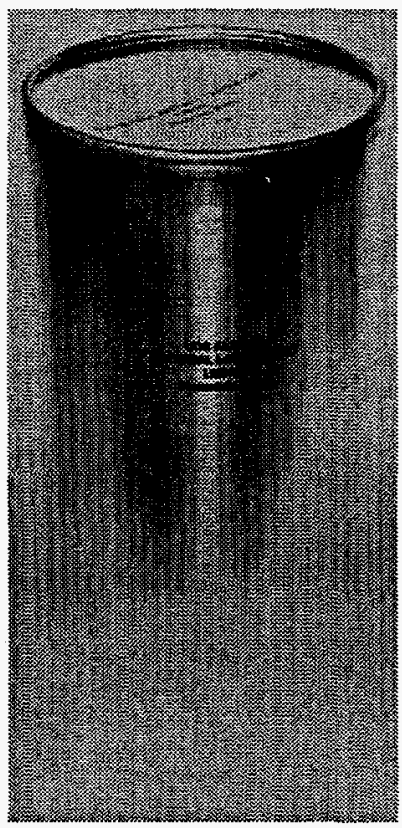

\section{Product}

- The product is plutonium oxide powder or a plutonium metal ingot

- The ingot is mounted vertically in the storage container with a "taco holder"

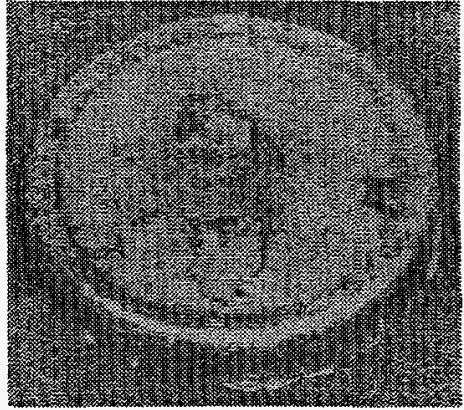

- Oxide powder ís simply poured into the container

Storage Container

- The container is welded stainiess steel and is backfilled with helium, an inert gas

- It is designed to meet the requirements for long term storage ( $>50$ years)

Fig. 2. Plutonium cast into a metal ingot and the storage container for metal or oxide.

The first five module tasks include the design, fabrication, and testing of the equipment, and installation of a module unit and its associated equipment into its glovebox. The sixth module, which incorporates NDA, will be entirely outside of the glovebox environment and uses robotic automation. Figure 3 shows the ARIES demonstration layout. The NDA module could be placed at one end of the production line, or opposite the production line, according to preference or space limitations. 




Fig. 3. ARIES demonstration layout.

- The final, or seventh, task consists of all the activities necessary to integrate the individual modules into an operational system within the Los Alamos Plutonium Facility. This task includes facility preparation activities, design and assembly of a conveyer system compatible with all the modules, acquisition of the gloveboxes, design and assembly of a control system to operate the integrated assembly, and preparation of all system documentation requirements. Additionally, this final task represents the integrated initial demonstration of the dismantlement of the nuclear weapon primaries. 
The test plan for the demonstration involves disassembly of sufficient numbers and types of pits from the weapons stockpile to provide confidence in the ARIES design and operation. For the initial demonstration, only pits with a straightforward design configuration will be processed. (Because seven pit types have been identified as meeting this criterion, these pits are sometimes referred to as the "seven dwarfs.") $)^{2}$ Selection criteria are outlined in section 4.6.

\subsection{BRIEF HISTORY}

In October 1994, the Secretary of Energy and the US Congress created the Office of Fissile Materials Disposition (OFMD) within the DOE. The OFMD was given responsibility for the DOE's technical and management activities in two major areas. First, DOE activities must provide a safe, secure, and environmentally sound storage option for all weapons-usable fissile materials in a form that can be quantifiably verified by NDA and inspected by international entities. Second, the DOE must provide disposition options for those fissile materials declared surplus to national defense needs. Beginning in fiscal year (FY) 1995, ARIES was sponsored by the OFMD. The ARIES Demonstration Project first received funding in FY96.

In 1992 the Nuclear Materials Technology (NMT) Division began several research and development activities to find a system to remove excess weapons-grade plutonium from pits. One of the original objectives of the ARIES Demonstration Project is to demonstrate the feasibility of a process that emphasizes pollution prevention for disassembly, extraction, and conversion of plutonium from weapon components into forms suitable for disposition and/or storage. Currently, no integrated system exists for the complete dismantlement and recovery of nuclear material from different weapons designs. A second objective of ARIES is to develop and demonstrate feasibility of a modular processing system that could be used by both the US and Russia. 


\subsection{ORGANIZATION}

The ARIES Demonstration Project encompasses all administrative, technical, engineering, procurement, and demonstration tasks necessary for design, purchase or fabrication, installation, cold (nonradioactive) testing, hot (radioactive) start-up, and operation of the complete system. ARIES is conducted as a cooperative program among Los Alamos National Laboratory, Lawrence Livermore National Laboratory (LLNL), and Sandia National Laboratories, New Mexico, with Los Alamos as the lead laboratory. The Los Alamos Nuclear Materials and Stockpile Management (NMSM) Program office is responsible for overall administration of the ARIES Demonstration Project. The LLNL Nonproliferation/Arms Control/Special Materials and Applications Program (SMAP) is responsible for administration of the Livermore portions of the ARIES Program.

NMT Division at Los Alamos is responsible for overall project management and system implementation of ARIES, as well as the operation of Technical Area (TA) 55. The ARIES Prototype Demonstration Project Leader, Timothy Nelson, is a technical staff member in the Advanced Technology Group, NMT-6.

\subsection{ARIES DEMONSTRATION PROJECT ACCOMPLISHMENTS DURING THE FIRST YEAR, FY96}

The following is a list of highlights for each module task taken from the ARIES FY96 monthly reports.

\subsection{Pit Bisection Module}

- Acquired approval of Los Alamos' Configuration Management for LLNL's pit bisector glovebox design, submitted design for competitive bid, and awarded contract to the vendor in September.

- Operated the MOD 1 pit bisector at LLNL and performed five bisections on three different war reserve (WR) pit types. These bisections demonstrated: (1) the bisection operation can be completed in less than 30 minutes, (2) the basic principle 
of a vertical axis bisector is valid, and (3) alignment of simple pit designs is not critical. A photograph of the pit bisector is shown in Fig. 4.

- Assembled the MOD 2 pit bisector and cold tested it on surrogate parts at LLNL.

- Submitted the Bisector Six: Month Progress Report. ${ }^{3}$

- Tested the Los Alamos-designed part-holding fixture successfully on LLNL's bisector using two significantly different-sized mockups. This fixture will be used on ARIES because it shields the operator from measurable exposure during part setup. The fixture is shown in Fig. 5.

- Performed hot bisection with the MOD 2 bisector after an operational readiness review in the Superblock, the LLNL plutonium facility.

- Revised the glovebox design for the advanced parting lathe, completed the mockup plywood glovebox, and installed the lathe.

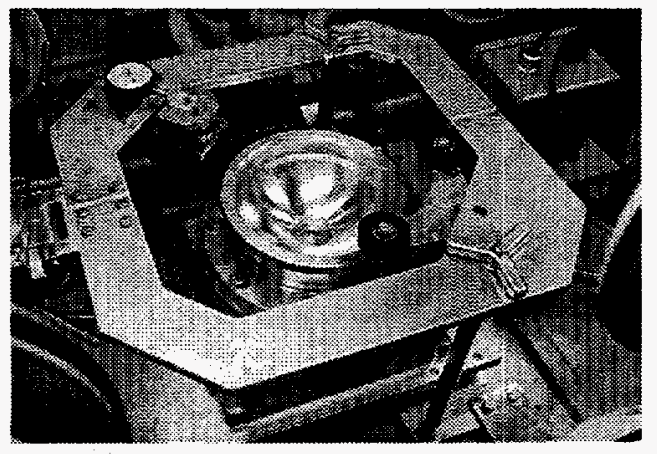
- Separates the component into hemishells
- Uses a cutting wheel similar to a tubing cutter or can opener
- Swages the component, producing no primary waste stream of sawdust or chips

Fig. 4. JPhotograph of the pit bisector. 
- Designed to hold a range of part sizes by drawing vacuum between large diameter O-rings

- Simplifies loading of parts

- Significantly reduces radiation exposure to disassembly workers

- Successfully tested on LLNL's pit bisector

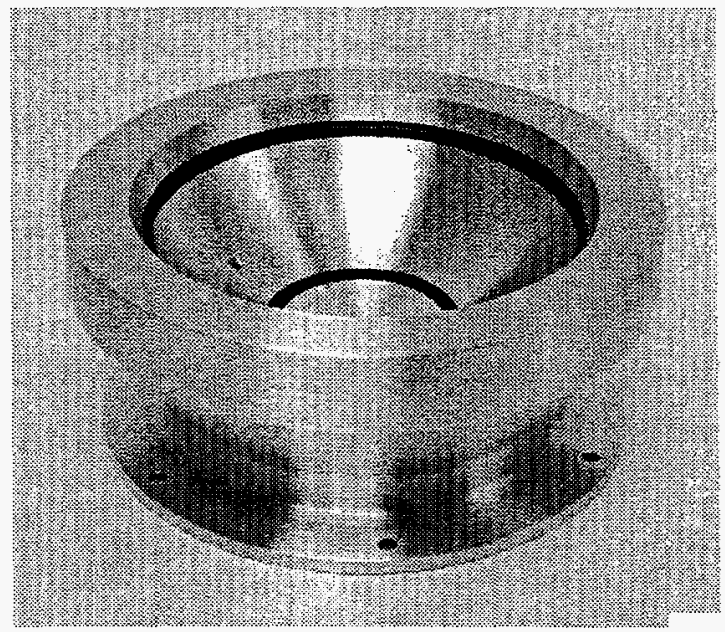

Fig. 5. Photograph of the Los Alamos-designed part-holding fixture.

\subsection{Hydride-Dehydride Recycle Module}

- Selected vendor, manufactured, and received two custom vacuum chambers for the hydride-dehydride recycle system. The hydride-dehydride recycle process is illustrated in Fig. 6. The two furnaces procured for the ARIES Demonstration Project can be seen in Fig. 7.

- $\quad$ Designed, procured parts, and began building four furnace controllers.

- $\quad$ Continued to test various concepts for a reusable crucible.

- $\quad$ Received all the certified components needed for the hoist on the prototype system.

- Tested motion control components.

- Completed the design, approval, and vendor selection for modifications to the ARIES Demonstration Project hydride-dehydride glovebox. Because the OFMD requested that funds be used to support mixed plutonium-uranium oxides (MOX) fuel research, procurements to modify the hydride-dehydride glovebox were delayed until FY97. 

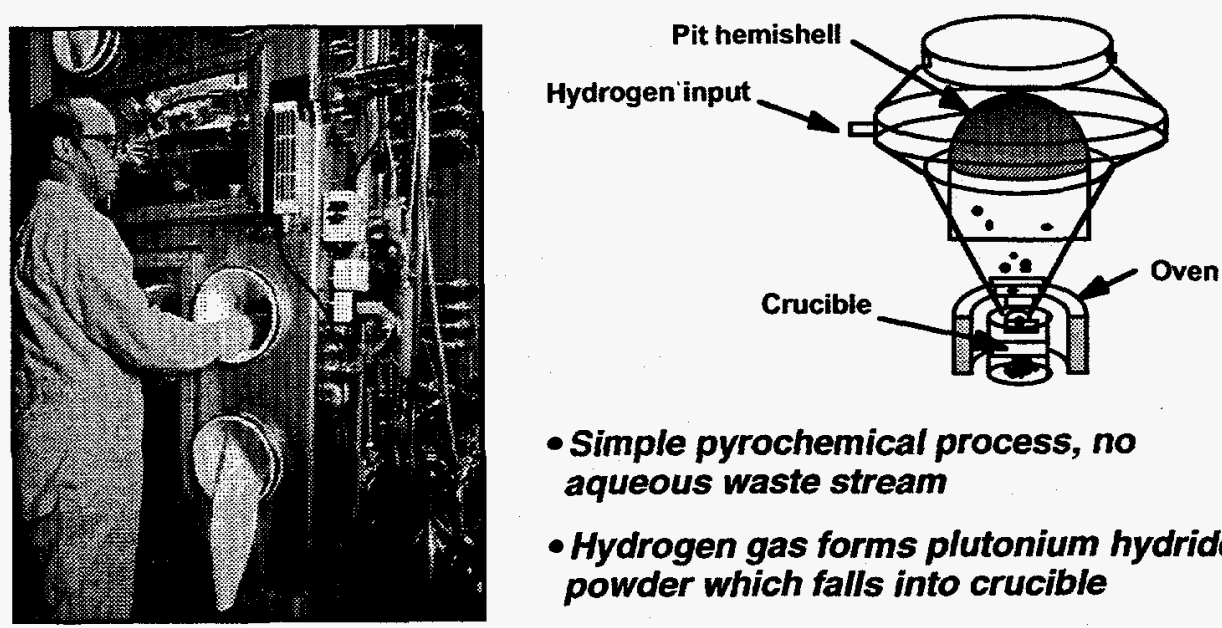

- Simple pyrochemical process, no aqueous waste stream

- Hydrogen gas forms plutonium hydride powder which falls into crucible

- For plutonium metal product, crucible is kept hot, driving hydrogen out, leaving metal "button"

- Product is recast to nominal mass for packaging

Fig. 6. The hydride-dehydride recycle process.
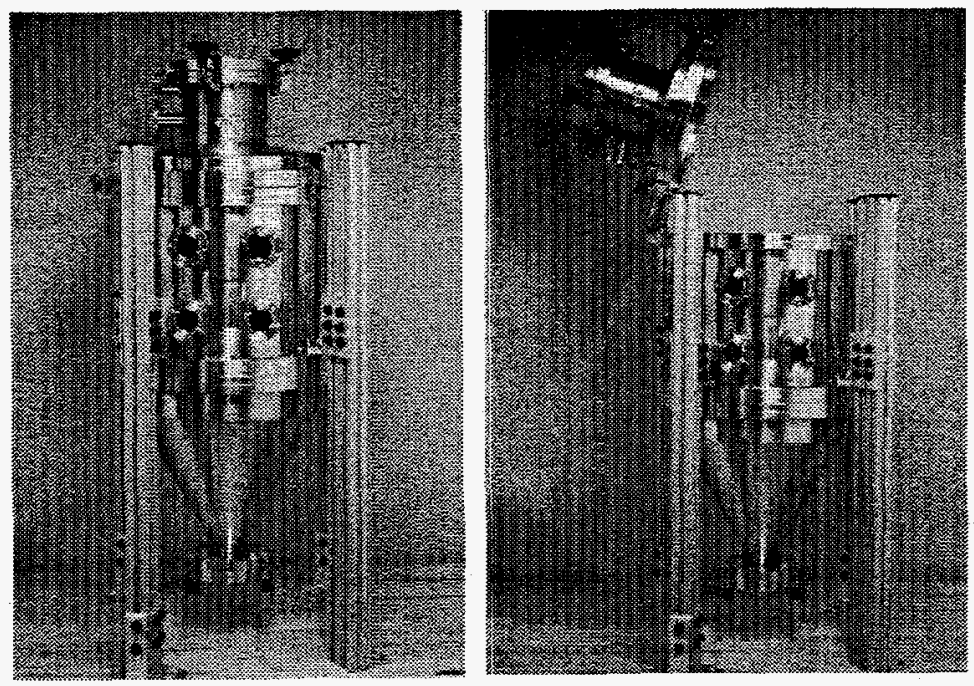

- Two furnaces were procured, providing a backup for the ARIES Demonstration

Project

Fig. 7. Two furnaces procured for the ARIES Demonstration Project.

\subsection{The Hydride-Oxidation Module}

- Secured approval for LLNL's HYDOX glovebox design from Los Alamos'

Configuration Management, submitted design for competitive bid, and awarded contract to the vendor in September. 
- Evaluated three processes to convert plutonium metal into plutonium dioxide $\left(\mathrm{PuO}_{2}\right)$ by hydriding: (1) hydriding/nitriding/oxidation process, (2) hydriding/oxidation process (the two-step HYDOX process), and (3) hydriding/oxidation process (the one-step, or cyclic, HYDOX process).

- Concluded that the one-step, or cyclic, HYDOX process was ineffective.

- Completed the HYDOX Six Month Progress Report. ${ }^{4}$

- Cold tested the dustless transfer system design and operation; received favorable review by LLNL's Superblock Facility Engineering design review committee for use in hot operations.

- Completed assembly of the initial design for the prototype HYDOX module. Figure 8 describes the HYDOX process.
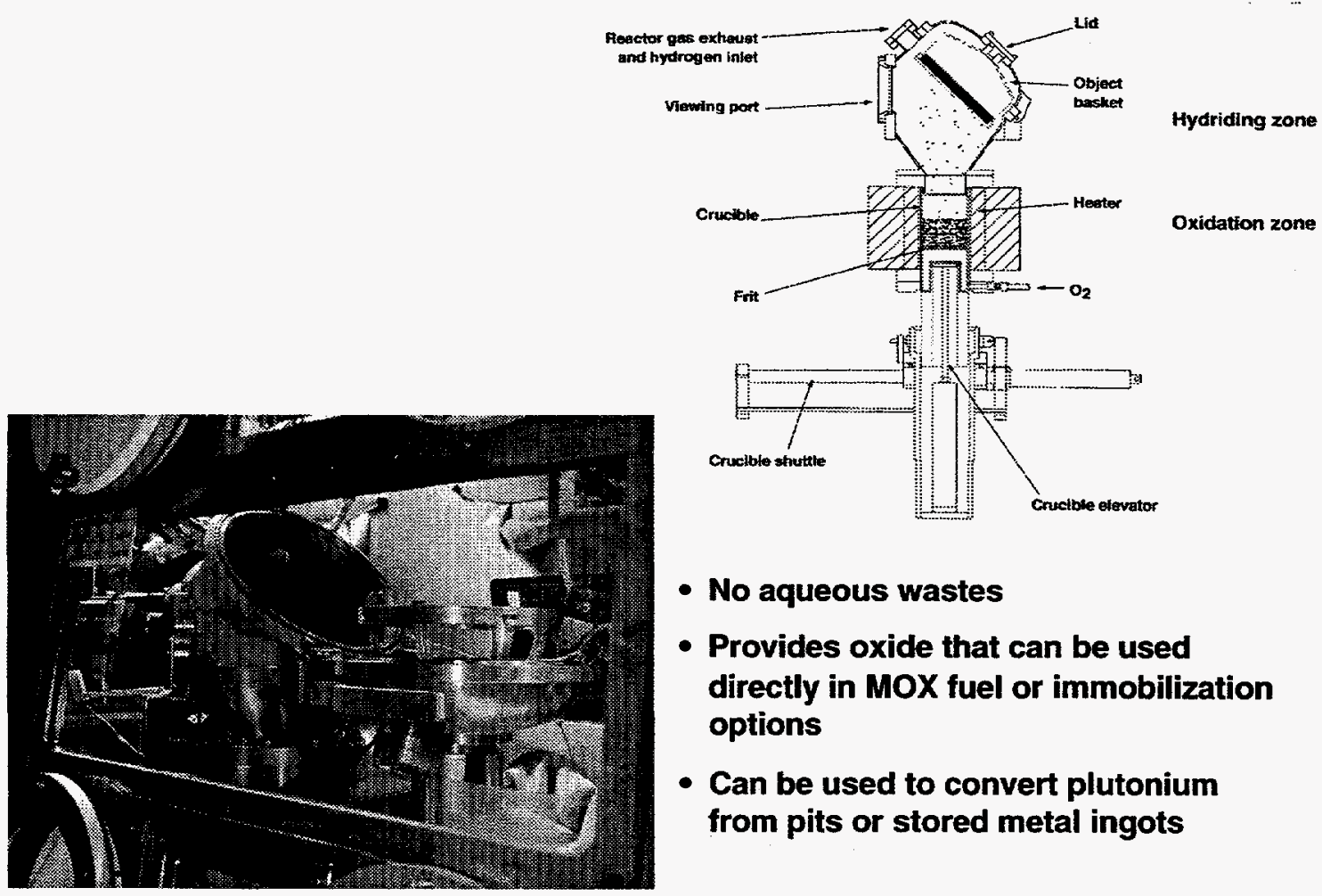

- No aqueous wastes

- Provides oxide that can be used directly in MOX fuel or immobilization options

- Can be used to convert plutonium from pits or stored metal ingots

Fig. 8. HYDOX module used to convert plutonium metal into plutonium oxide. 


\subsection{The Canning Module and Electrolytic Decontamination Module}

- Conducted extensive systematic investigations of current density, metal removal rate, $\mathrm{pH}$, and electrolyte concentration for different electrolytes.

- Performed hot coupon tests with a new electrolyte demonstrating impressive material removal rates.

- Demonstrated electrolytic decontamination of containers and our capability to remove them from the glovebox environment. ${ }^{5}$

- Designed, fabricated, and tested stainless steel product inner cans that comply with DOE-STD-3013-96 ${ }^{1}$ with welds located about 1 inch from ends. ARIES product inner can burst tests results can be seen in Fig. 9. The deep-drawn inner cans were burst tested and tested for integrity after being pressurized. Outer cans fabricated to the specifications of the British Nuclear Fuels, Ltd. (BNFL) design were also burst tested. Although not required by DOE-STD-3013-96, ${ }^{1}$ burst tests were conducted as a double check on can strength. The cans burst consistently at pressures above $3000 \mathrm{psi}$. An inner can maintained its leak tightness after being pressurized to $750 \mathrm{psi}$, in accordance with section 4.2.1, paragraph (f) of DOE-STD-3013-96. ${ }^{1}$ Drop tests of can packages containing a simulated load are in progress at BNFL.

- Investigated several alternate electrolyte systems for the decontamination process; sulfate systems were selected as the most attractive.

- Assembled full-scale ultrafiltration unit for use in the electrolytic decontamination process. Figure 10 is a photograph of the Electrolytic Decontamination module apparatus mockup for the ARIES Demonstration Project. Figure 11 is a close-up of the decontamination chamber, including a product can.

- Demonstrated in situ electrolytic decontamination of gloveboxes contaminated with transuranic (TRU)-level waste to low-level waste (LLW). This application for glovebox decontamination is shown in Fig. 12. We removed a single-station glovebox and transferred it to another location, recycled two gloveboxes, and disposed of another 
glovebox as LLW, the first glovebox from TA-55 to be disposed of as LLW. This effort represents a substantial cost savings because some of the gloveboxes can now be reused, saving the cost of purchasing a new glovebox. The potential TRU-level waste cost savings are estimated to be hundreds of thousands of dollars. Proper disposal of the glovebox would have been impossible because there is currently no location for TRU waste disposal until the Waste Isolation Pilot Project opens. Also, this effort represents an increase in worker safety by reducing the potential for contamination, as well as reducing the amount of potential contamination should an incident occur during removal and subsequent processing of the glovebox.

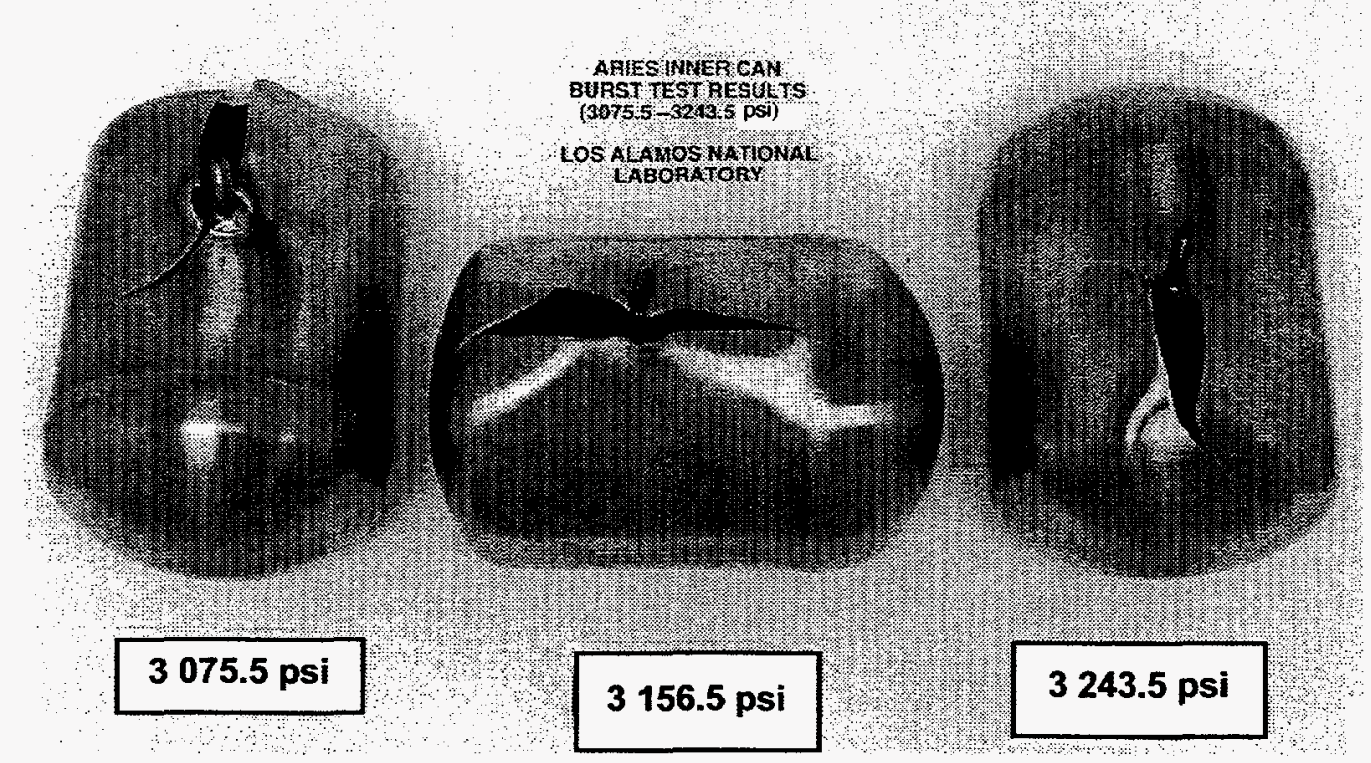

- Bursts initiated at stem-artifact of test

- DOE STD 3013 requires an inner can to maintain its leak tightness to 750 psi

Fig. 9. ARIES inner can burst test results. 


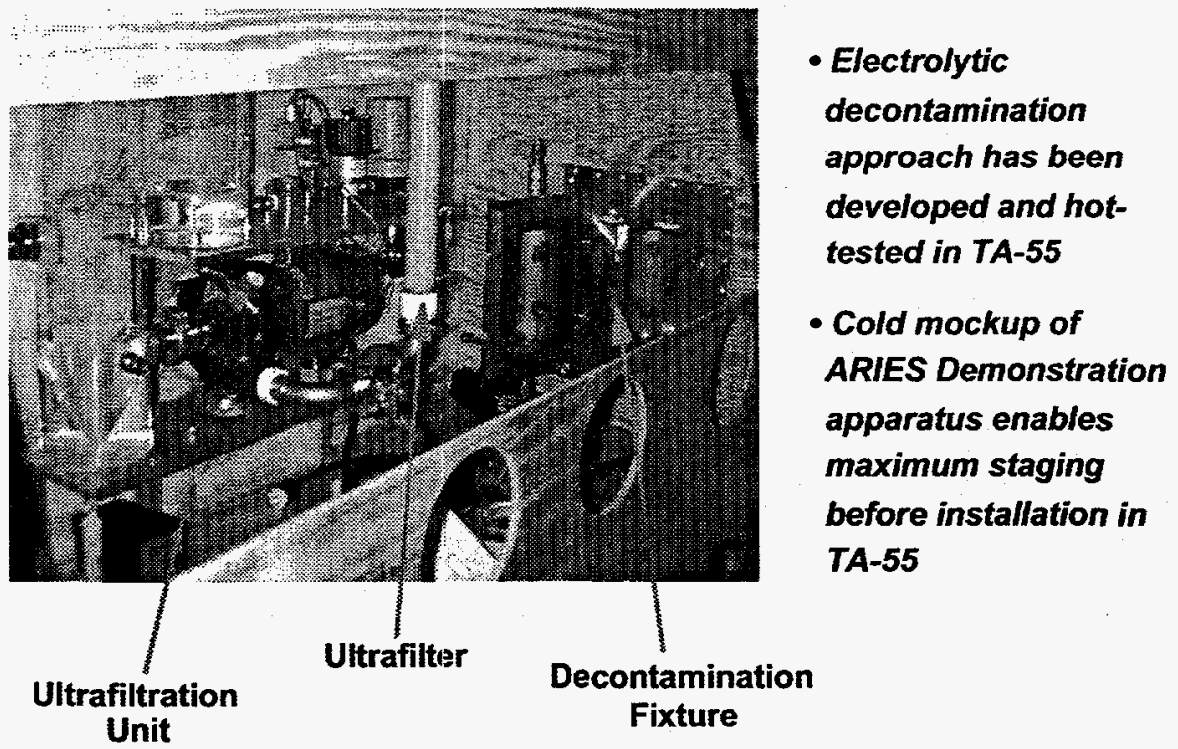

Fig. 10. Mockup of the Electrolytic Decontamination module apparatus.

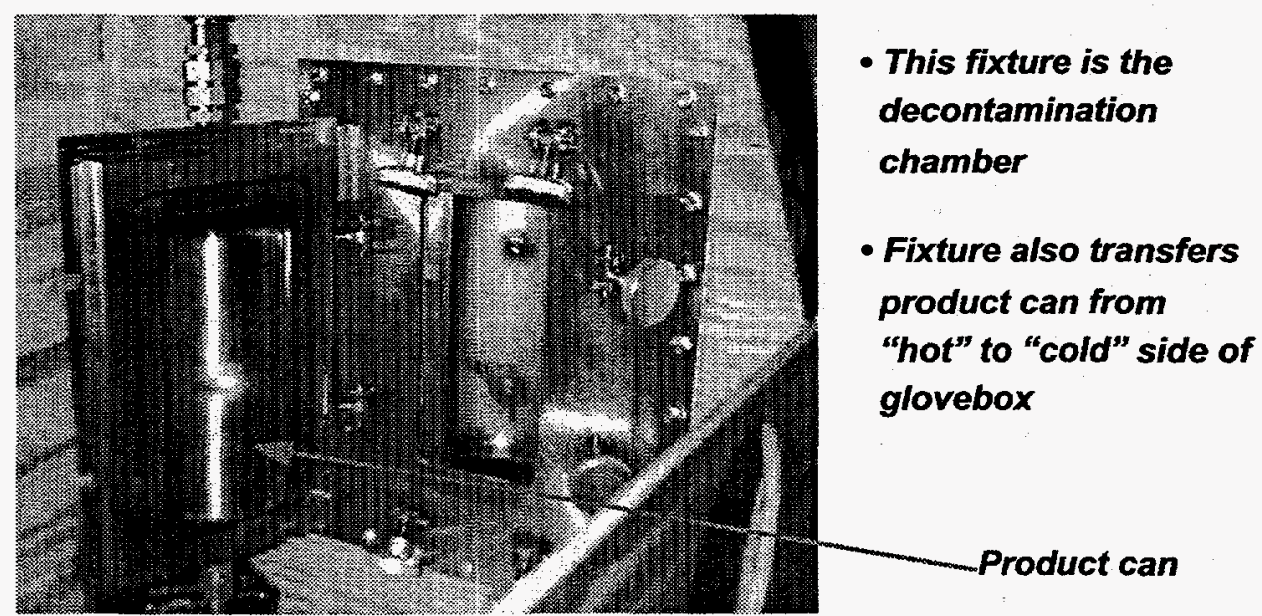

Fig. 11. Close-up view of the decontamination chamber.

- Completed the design, approval, and vendor selection for modifications to the electrolytic decontaminatior demonstration gloveboxes.

- Operated an integrated can decontamination-ultrafiltration system consisting of two flow loops. Figures 13 and 1.4 are diagrams of the electrolytic decontamination process and of the glovebox with its division into two chambers: a hot side for receiving the material container that holds the product from either the HYDOX or Hydride-Dehydride Recycle module, and a cold side for receiving the decontaminated material can. 
- Purchased the laser marking system, welding stations, containers, and video cameras for the packaging system.



Glovebox decontamination

- Electrolytic decontamination is being applied to decommissioning and decontamination (D\&D) of gloveboxes

- A fixture with a rubber gasket is placed on glovebox wall

- Electrolyte is pumped into and out of the fixture

- Output pump is stonger, creating a partial vacuum to hold fixture in place

- Glovebox can be disposed as lowlevel waste rather than transuranic waste, representing substantial cost savings

Fig. 12. In situ electrolytic decontamination of gloveboxes. 


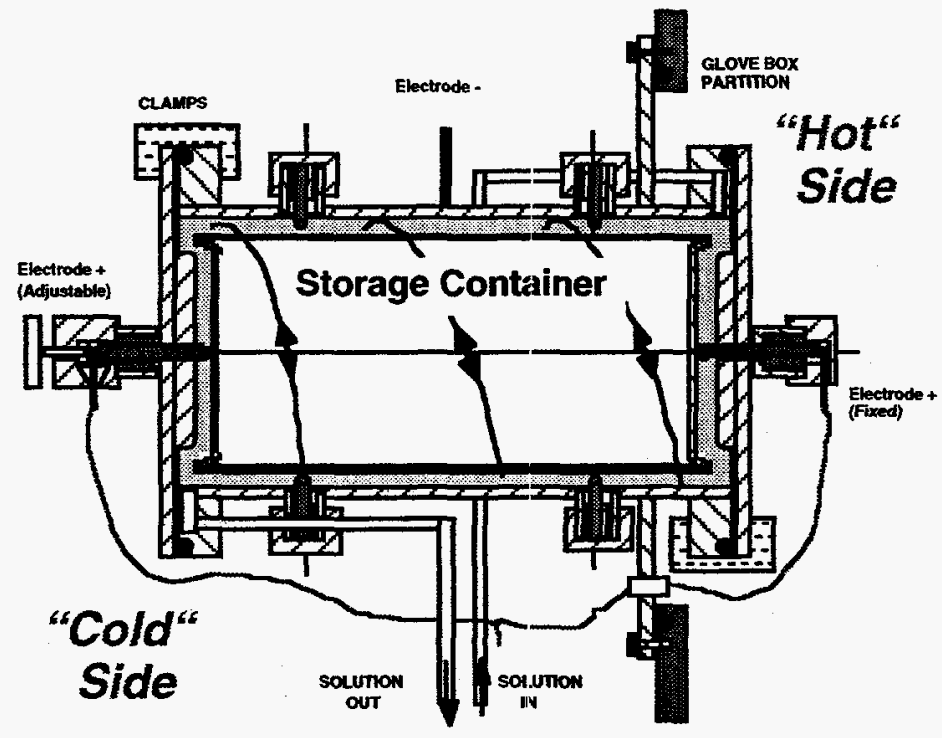

- Application of current removes contamination

- The electrolyte is sodium sulfate solution

- Plutonium, uranium, and stainless steel are insoluble in the electrolyte, and are removed by filtration

- The electrolyte is reused throughout the campaign

Fig. 13. The electrolytic decontanaination demonstration glovebox. The hot side is for receiving the product from the HYDOX or Hydride-Dehydride Recycle module and packaging the product in the material container; the cold side is for receiving the decontaminated product can.

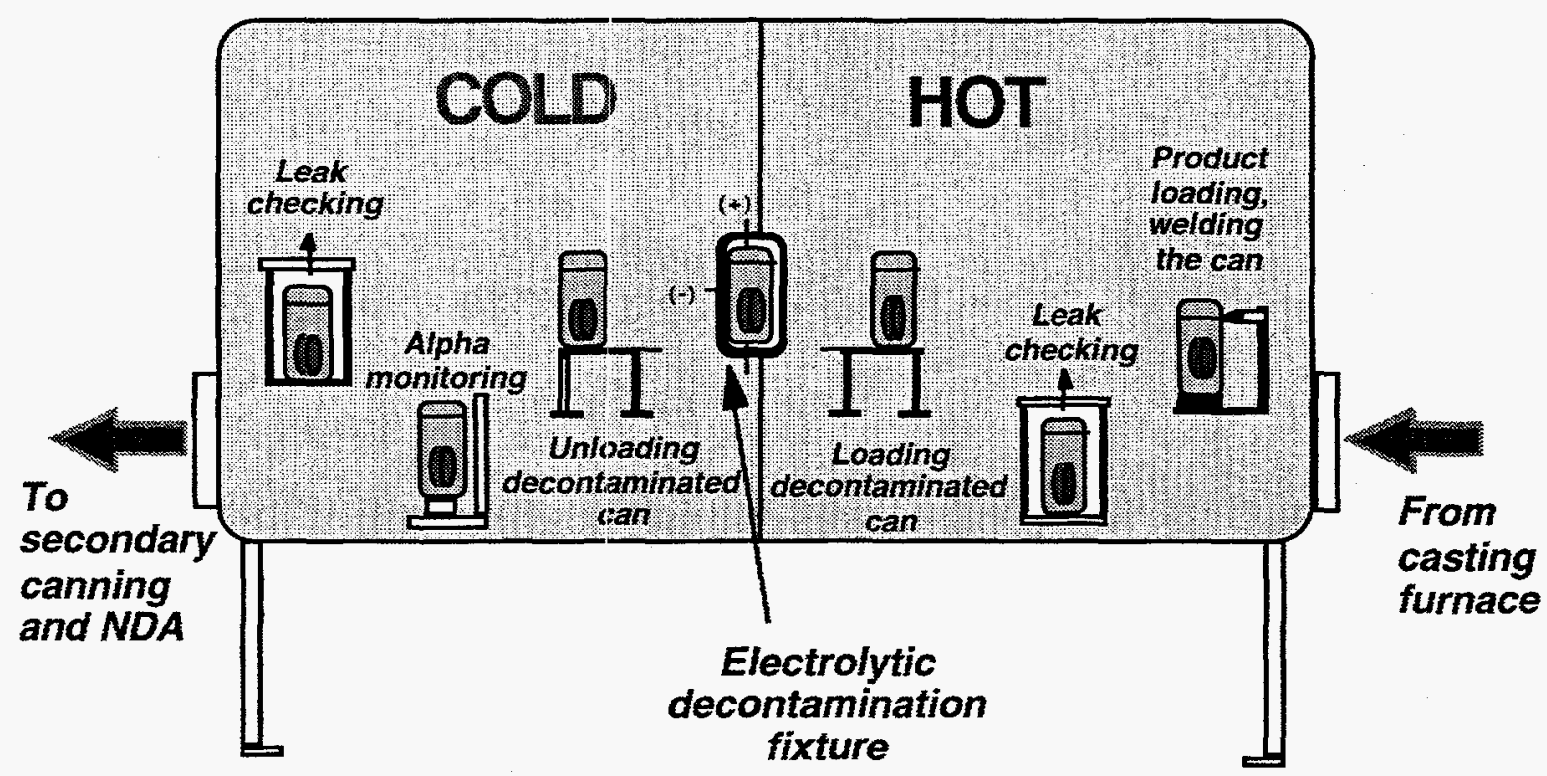

Fig. 14. The electrolytic decontamination demonstration glovebox showing the decontamination process. 


\subsection{Nondestructive Assay System/Robotic Automation Module}

- Made significant progress on both the segmented gamma scanner system and the plutonium isotopic composition system to interface with the stepping motor hardware. Demonstrated the stepping motor control from both systems. The plutonium isotopic composition system has demonstrated mock measurements under host computer control. Both the segmented gamma scanner system and the plutonium isotopic composition system are shown in Fig. 15.

- Implemented the host computer program that permits an operator to select a sample and place the sample in an instrument for the purpose of analysis. The program sequences the stacking of the neutron coincidence counter (NCC) instrument according to the configuration selected by the operator. Sensors are checked before stacking to prevent movement into occupied locations. This program also demonstrates coordination of the environment position sensors with robotic operations. Figure 16 shows a robotic arm positioned above an instrument before loading a sample to be measured.

- Completed fabrication of wells for scanning.

- Assigned additional personnel to work on the NDA robotic system to complete modifications required for new can style.

- Received ${ }^{75}$ Se source and installed the collimator. The collimator must be modified to reduce the diameter of the aperture because the beam is too hot.

- Completed development of gamma-ray isotopic system (GRIS) software for the assay of high plutonium-content items.

- Assembled and operated calorimeter received from Mound. The calorimeter is pictured in Fig. 17. 


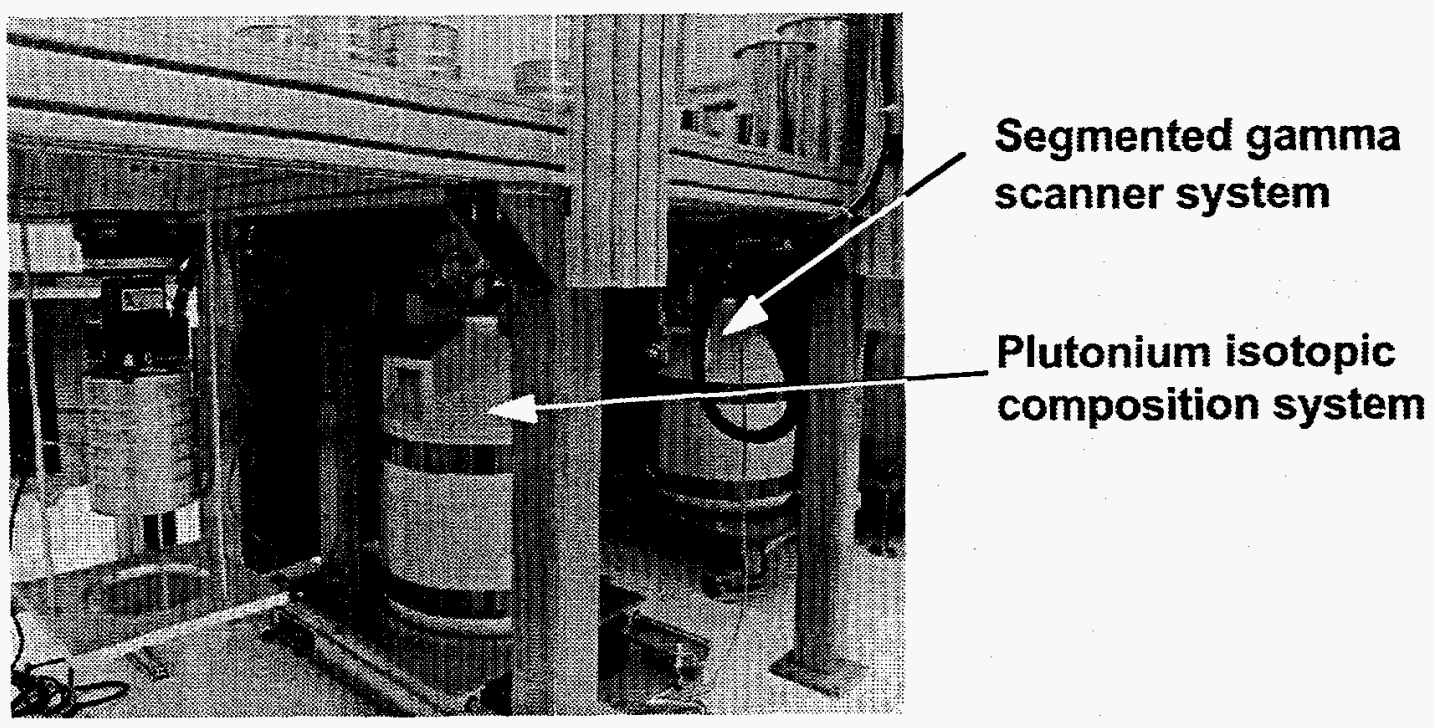

- High-purity germanium detectors require liquid nitrogen cooling

- Segmented gamma scanner measures ${ }^{239} \mathrm{Pu}$ in low-density waste

- Plutonium Isotopic composition measurement is required to interpret calorimetry and neutron counting data

Fig. 15. Photograph of the segmented gamma scanner system and the plutonium isotopic composition system.

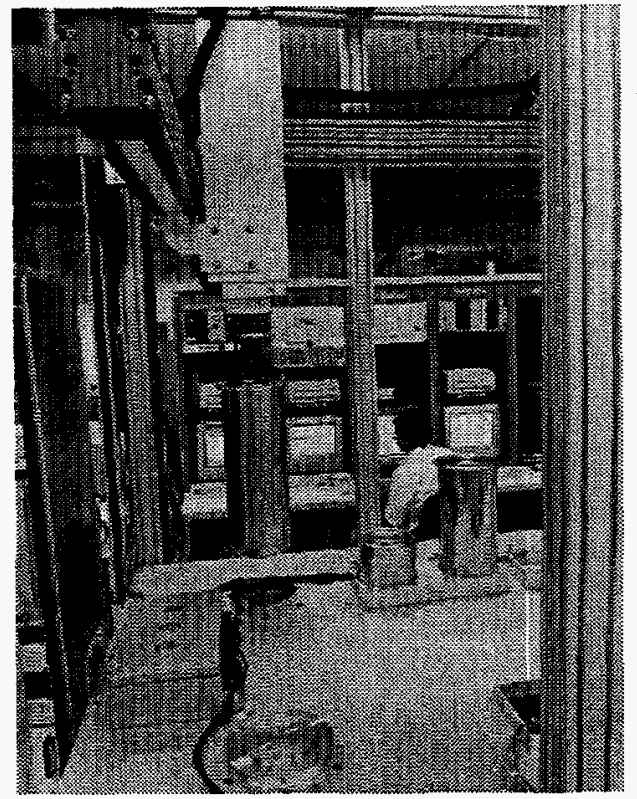

No glovebox

- Product and waste cans already decontaminated

Assay components

- Gamma spectrometer: isotopics

- Segmented gamma scanner: waste assay

- Neutron counter: waste assay

- Calorimeter: product assay

Automation/robotics

- Telescoping gantry system

- Radiation-hardened efectronics

- Increased throughput

- Reduced worker exposure

Fig. 16. Robotic arm positioned above an instrument before loading a sample to be measured. 


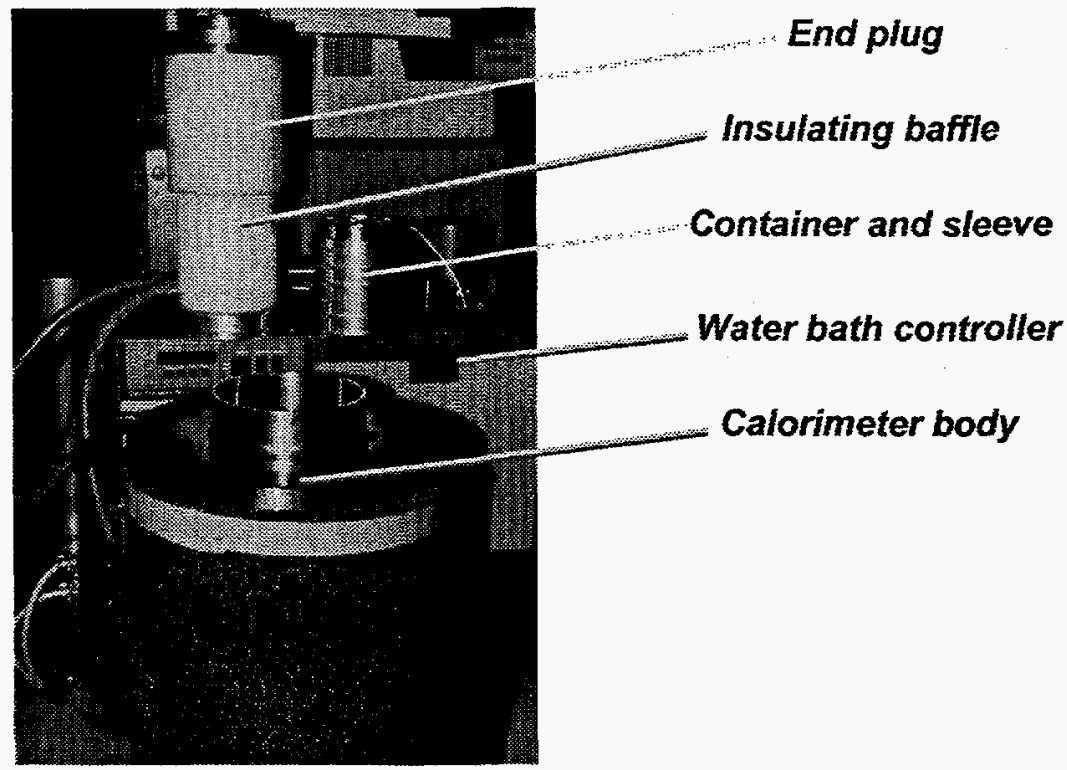

Fig. 17. Photograph of the calorimeter before installation in the NDA system.

\subsection{Facility Assembly and System Integration}

- Designed and fabricated a three-dimensional model of the ARIES glovebox system for use by DOE personnel.

- Completed, approved, and work is nearly completed on the Phase 1 work package, which is a detailed procedure for decommissioning and decontamination (D\&D) of the ARIES room. Under development are the Phase 2 work package, which is a detailed procedure for glovebox relocation, and the Phase 3 work package, which describes glovebox installation in the ARIES room.

- Began equipment assembly to support cold-testing demonstration planned for TA-46 while TA-55 was shut down for the Operations Center Upgrade Project.

- Started a glovebox mockup of the ARIES conveyor system. The conveyor gloveboxes are pictured in Fig. 18; the cold mockup of the conveyor cart can be seen in Fig. 19.

- Conducted a comprehensive study to identify pit designs that represent a large fraction of the retirement stockpile for future disposition and that could be processed using ARIES demonstration technologies. Selection criteria for pits include: design, 
quantity available in the retirement stockpile, potential exposure for the workers, and logistical ease to acquire pits for the demonstration.

- Received approval of the ARIES Integrated Test Plan ${ }^{2}$ from the DOE OFMD. Requested DOE/Albuquerque Operations Office (AL) authorize shipment of pits from Rocky Flats Environmental Technology Site and Pantex according to the schedule in the classified addendum to the ARIES Integrated Test Plan.

- Developed and submitted many design change packages to Configuration Management for approval. Table 1 sumraarizes this effort.

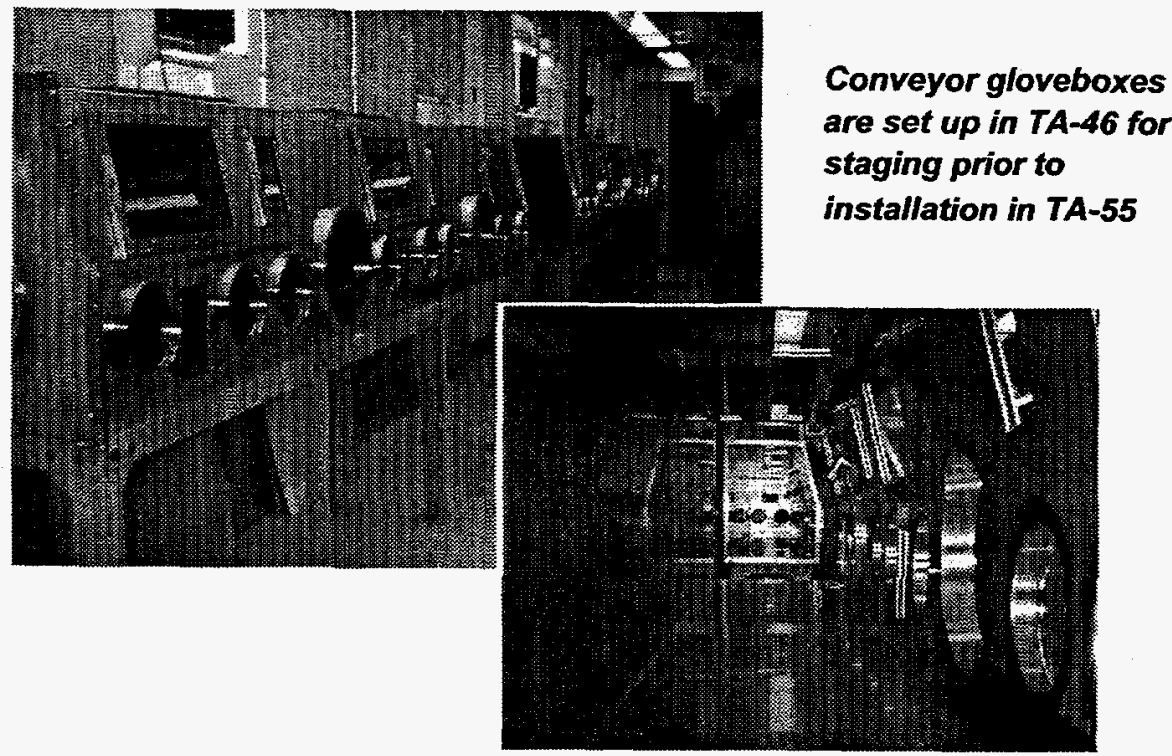

Fig. 18. Photographs of the exterior and interior of the conveyor gloveboxes. 

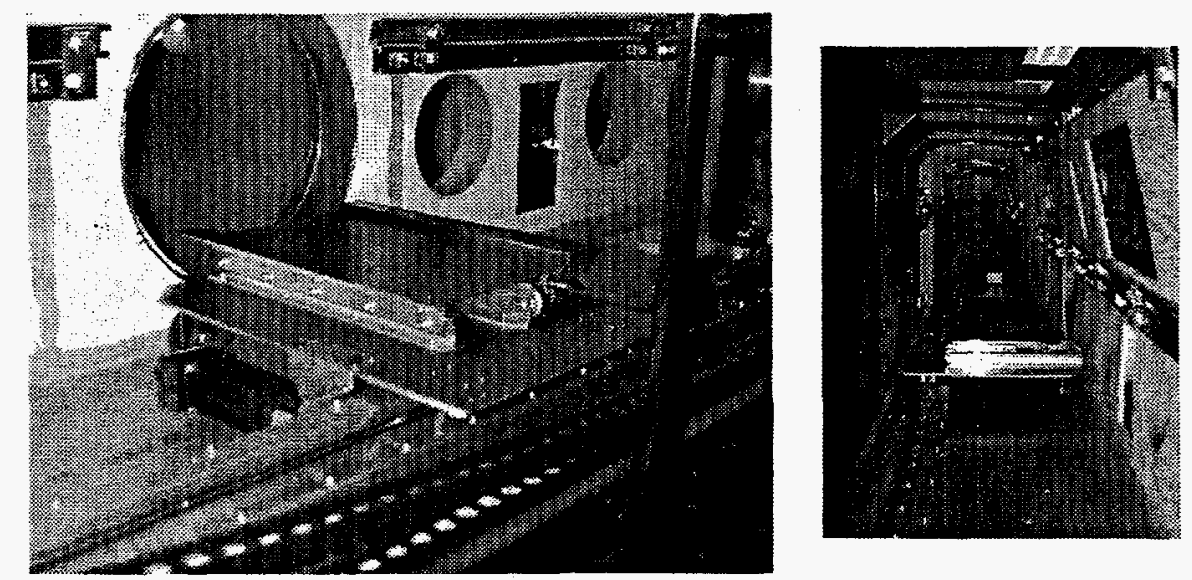

- Cart is being developed in a cold mockup of the conveyor system at TA-46 prior to installation in the TA-55 Plutonium Facility

Fig. 19. Photographs of the conveyor cart mockup.

TABLE 1

Design Change Package Summary

\begin{tabular}{|c|c|c|c|c|}
\hline $\begin{array}{c}\text { DESIGN } \\
\text { CHANGE } \\
\text { PACKAGE } \\
\text { NUMBER }\end{array}$ & $\begin{array}{c}\text { REVIEW AND } \\
\text { APPROVAL } \\
\text { START DATE }\end{array}$ & $\begin{array}{c}\text { RELEASE FOR } \\
\text { CONSTRUCTION } \\
\text { COMPLETION } \\
\text { DATE }\end{array}$ & $\begin{array}{c}\text { WORK } \\
\text { REQUEST } \\
\text { NUMBER }\end{array}$ & $\begin{array}{c}\text { PROJECTED } \\
\text { COMPLETION } \\
\text { DATE }\end{array}$ \\
\hline $\begin{array}{l}96-026 \mathrm{~A} \\
96-026 \mathrm{~B}\end{array}$ & $\begin{array}{l}19 \text { Dec } 1995 \\
16 \text { May } 1996\end{array}$ & $\begin{array}{l}14 \text { Feb } 1996 \\
29 \text { May } 1996\end{array}$ & $\begin{array}{l}9601012 \mathrm{~A} \\
9601012 \mathrm{~B}\end{array}$ & $\begin{array}{l}3 \text { May } 1996 \\
8 \text { Jan } 1997\end{array}$ \\
\hline 96-026B1 & 16 May 1996 & 18 Nov 1996 & $9601012 \mathrm{~B} 1$ & Ongoing \\
\hline $96-026 \mathrm{C}$ & 9 Apr 1996 & 18 Apr 1996 & $9601012 \mathrm{C}$ & 10 Oct 1996 \\
\hline $96-026 \mathrm{D}$ & 9 Apr 1996 & 18 Apr 1996 & 9601012D & 10 Oct 1996 \\
\hline $\begin{array}{l}96-026 \mathrm{E} \\
96-026 \mathrm{E} 1\end{array}$ & $\begin{array}{l}16 \text { May } 1996 \\
16 \text { May } 1996\end{array}$ & $\begin{array}{l}29 \text { May } 1996 \\
16 \text { Dec } 1996\end{array}$ & $\begin{array}{l}9601012 \mathrm{E} \\
9601012 \mathrm{E} 1\end{array}$ & $\begin{array}{l}8 \text { Jan } 1997 \\
\text { Ongoing }\end{array}$ \\
\hline $\begin{array}{l}96-026 \mathrm{~F} \\
96-026 \mathrm{~F} 1\end{array}$ & $\begin{array}{l}16 \text { May } 1996 \\
16 \text { May } 1996\end{array}$ & $\begin{array}{l}29 \text { May } 1996 \\
16 \text { Dec } 1996\end{array}$ & $\begin{array}{l}9601012 \mathrm{~F} \\
9601012 \mathrm{~F} 1\end{array}$ & $\begin{array}{l}8 \text { Jan } 1997 \\
\text { Ongoing }\end{array}$ \\
\hline $\begin{array}{l}96-026 \mathrm{G} \\
96-026 \mathrm{G} 1\end{array}$ & $\begin{array}{l}5 \text { Jun } 1996 \\
5 \text { Jun } 1996 \\
\end{array}$ & $\begin{array}{l}5 \text { Jun } 1996 \\
16 \text { Dec } 1996\end{array}$ & $\begin{array}{l}9601012 \mathrm{G} \\
9601012 \mathrm{G} 1\end{array}$ & $\begin{array}{l}8 \text { Jan } 1997 \\
\text { Ongoing }\end{array}$ \\
\hline
\end{tabular}


- Completed the following documents:

1. ARIES Project Quality Assurance Plan, ${ }^{6}$

2. ARIES Program Plan, ${ }^{7}$

3. ARIES Technical Task Plans/Statements of Work for FY $96,{ }^{8}$

4. ARIES Preconceptual Design Report, ${ }^{9}$

5. ARIES Instrumentation and Control System (ICS) Man-Machine Interface Design Standard, ${ }^{10}$

6. ARIES ICS Parameter Name Design Standard, ${ }^{11}$ and

7. ARIES Integrated Test Plan. ${ }^{2,12,13}$

- In addition to the required documents listed above, during the past year we published abstracts for various conferences and for foreign visitors, and several articles on ARIES, including the following:

“ARIES Dismantling Reduces DOE's Plutonium Stockpile," 14

"New Technologies Convert Fissile Materials for Indefinite Storage," 15 and

The Los Alamos National Laboratory Annual Report to the Regents University of California. ${ }^{16}$

- Conducted design reviews of all the modules and special systems composing the ARIES: pit bisector, hydride-dehydride recycle, HYDOX, canning, electrolytic decontamination, instrumentation and control system, conveyor system (including cart and shuttle), three gloveboxes and airlocks, hoist systems, and operator controls for the bisector, NDA, and robotics.

- Developed software for the programmable logic controller (PLC), including configuration and communication between host computer and controller for conveyor.

- Began developing simulations of some of the ARIES processes in order to estimate worker exposure to radiation. This ongoing effort is being conducted by Sandia National Laboratories. 


\subsection{CONCLUSION AND FOLLOW-ON ACTIVITIES}

We made considerable progress during the first year of the ARIES Demonstration Project. The bisector operation developed the second generation bisector. The Hydride-Dehydride Recycle system performed many successful operations, and the second generation furnace/vacuum chamber was designed and built. The single-step research and development of HYDOX was completed. The research and development activities for the electrolytic decontamination of containers demonstrated feasibility, and through systematic research we selected a new, better electrolyte. We developed a series of container designs for use in the demonstration project that met DOE-STD-3013-96. ${ }^{1}$ A calorimeter was added to the NDA instrument rack. NDA robotics conducted an endurance run that successfully demonstrated more than the equivalent number of pick and place operations required for the initial integrated demonstration test. The conveyor system was successfully designed, reviewed, and demonstrated. All gloveboxes were designed and approved. The conveyor gloveboxes arrived and were ready for installation in accordance with the original schedule. The ARIES room preparation proceeded very well and was ready to receive the conveyor gloveboxes.

Some ARIES activities have not been as successful as we had hoped. For example, the HYDOX module is a true research and development task, and progress has been slow. During the design review of the module in July 1996, we selected the two-step process, hydriding followed by oxidation as the baseline. By the end of the fiscal year, process times were still long for both the two-step and the newer three-step process compared with estimated process times for direct oxidation. Eventually, there may be modifications to the furnace design or redesign of the furnace; however, we intend to operate a HYDOX module as part of the ARIES Demonstration Project.

In addition to the ARIES Demonstration Project, there is also interest in an ARIES Upgrade Project that would incorporate the lessons learned from the initial demonstration, upgrade some module activities, use 10-inch containers, incorporate the advanced parting lathe, 
and include more robotic automation to minimize worker exposure while they process pits from the retirement stockpile.

The third phase of the ARIES Demonstration Project is the design of the ARIES Pit Disassembly and Conversion Facility (PDCF), a full-scale production system at which disassembly and conversion will be performed on surplus weapons pits. The initial work concentrates on preparing documentation to support decisions leading to line-item construction funding. Information from the ARIES Demonstration Project will be expanded to predict the requirements of the production system. The functional requirements will identify all the facility and infrastructure requirements needed to support the objective of the PDCF.

\subsection{Schedule}

At the request of the OFMD, we delayed writing parts of this report until after we could assess the impact of the Operations Center Upgrade Project. The original ARIES schedule was ambitious. (This demonstration was planned as a 24-month program with full operation occurring during the last 3-6 months of FY97.) There was no slack time that could be used to absorb unforeseen complications such as preparation for the PF-4 Operations Center Upgrade Project that took three months directly from the ARIES installation schedule. Another month was lost indirectly from the Operations Center Upgrade Project because the ARIES Project had a lower priority, which meant a reduction in craft personnel, health physics technicians, and systems engineers. An additional two months has also been added to the original schedule to account for increasing review time for various readiness assessments. The new schedule for the ARIES Demonstration Project shows completion of a three-month demonstration by mid-1998.

\footnotetext{
* To support the ARIES flow sheet for pit disassembly and conversion facility, there is an initiative by Los Alamos to add a parting lathe automation module to the ARIES line. The objective is the selection and integration of an automated system to load and unload components to be processed in the parting lathe. The system will also be capable of selected disassembly operations, thus minimizing worker radiation exposure. The automated system should increase system throughput, yield greater consistency of process control during pit disassembly, and enable the safe disassembly of all pits in the current nuclear weapons stockpile.
} 
The Plutonium Facility's role is changing as a result of increased oversight that has necessitated a new way of doing business. There is a greater emphasis on scheduling, work control, work reviews, as well as the necessity of assessing planned work to ensure that all safety requirements are met and that all hazards analyses and operational readiness reviews are conducted. There is also a shortage of qualified/certified personnel to perform work required on ARIES and other work required to keep TA-55 operating in compliance with all environmental, safety, and health regulations. The number one priority of TA-55 management is to keep the facility open and accomplish our multi-use programmatic goals while ensuring that the facility meets the requirements of the Defense Nuclear Facility Safety Board (DNFSB), as well as both old and new DOE orders.

There are three critical path elements that adversely affect the schedule. The first is the time required for approval of design change packages. This is a major bottleneck due to shortage of systems engineers with the experience to review these technical documents, the implementation of new standards, and the priorities set by the facility. The second is glovebox installation, which has been slowed down by limited personnel resources (i.e., radiation control technicians [RCTs], skilled crafts, etc.). Limited personnel resources are being mitigated by facility management granting the ARIES Project certain concessions, including dedicated craft personnel, dedicated RCTs, an ARIES area work supervisor, and intensive team building among the personnel. The third critical path element is the safety reviews, shipping and receiving issues, hazards analysis reviews, and both group-level and facility team reviews required in an environment of changing standards and procedures. The ARIES Project has quality assurance (QA) staff who are instrumental in implementing procedures to comply with increased oversight, more stringent DOE orders, and any change in interpretation of old DOE orders. Our QA staff is incorporating the lessons learned from the recent Operations Center Upgrade Project and the Cassini Project to ensure that our reviews are met with success from the beginning. All of the corrective actions taken to affect these critical path elements should help contain any further slippage in the new schedule. 


\subsection{THE RUSSIAN INITIATIVE}

Figure 20 shows that disassembly and conversion fills the gap between classified pits and the disposition options for both the US and Russia. This work is the next step toward reducing global nuclear danger. Conversion of plutonium provides a product form that contains no design information, enabling its placement under broader, international inspection and safeguard regimes. Conversion can increase both transparency and irreversibility, and should proceed as quickly as possible for surplus weapons plutonium from both the US and Russia. ARIES showcases the US disassembly and conversion technology. Plutonium oxide derived from weapons using ARIES technology has been fabricated into MOX fuel.

The joint US-Russian program for pit conversion includes cooperative research and development, NDA, and material protection, control, and accountability, and a pit conversion pilot plant demonstration. The proposed prototype NDA system will be required to measure plutonium metal and oxide in the input and output containers, and the wastes and byproducts of the conversion process. The NDA system will also be used to safeguard the shipping process with a gamma-ray radiation monitor, and two calorimeters sized for measurements of the input and output containers. Other instruments in the NDA system include: a gamma-ray system for plutonium isotopic distribution measurements, a neutron counter, and the possibility of a segmented gamma scanner for measurement of low-density wastes. 


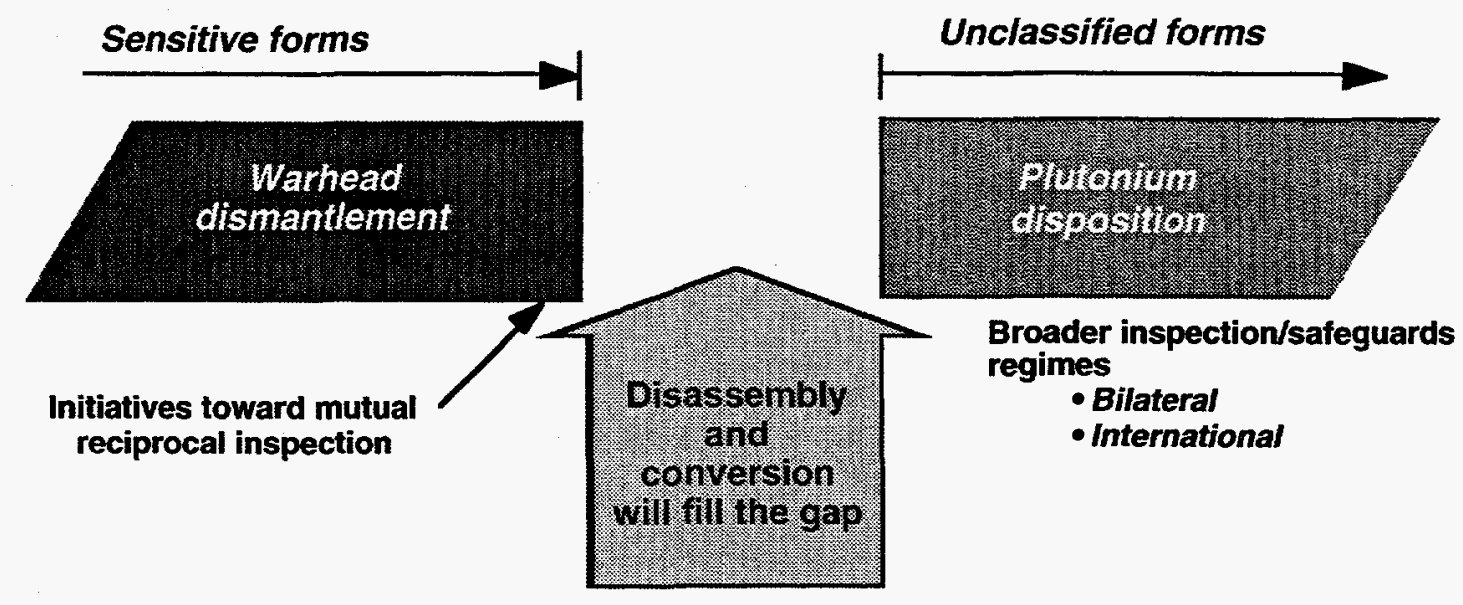

Goals for both nations

- Disassembly of surplus weapon components and conversion of plutonium to forms suitable for storage under broader safeguards and security regimes

- Conversion to forms suitable for disposition options

Fig. 20. Disassembly and conversion of plutonium fills the gap between classified pits and the disposition options for both the US and Russia.

\subsection{REFERENCES}

1. "Criteria for Preparing and Packaging Plutonium Metals and Oxides for Long-Term Storage," Department of Energy document DOE-STD-3013-96 (September 1996).

2. Timothy O. Nelson, Pamela Massey, Winslow Brough, Wendel Brown, and Mark C. Bronson, ARIES Integrated Test Plan, Los Alamos National Laboratory document LA-UR-96-3192 (September 11, 1996).

3. Dewey Ravenscroft, Winslow Brough, and Donald Pomplun, Bisector Six Month Progress Report, Lawrence Livermore National Laboratory document (July 1996).

4. Carlos A. Colmenares and Mark C. Bronson, HYDOX Six Month Progress Report, Lawrence Livermore National Laboratory document (July 1996).

5. Timothy O. Nelson, “ARIES: End of the First Quarter,” Los Alamos National Laboratory memorandum, NMT-6-ENG-95-014, to Larry Avens (December 21, 1995). 
6. David Dennison and Lawrence S. Kreyer, ARIES Project Quality Assurance Plan, NMT-6 Procedure OAP-101-R00 (January 26, 1996).

7. Timothy O. Nelson, Mark C. Brorsson, David K. Dennison, Pamela W. Massey, Teresa L. Cremers, Lawrence S. Kreyer, Advanced Recovery and Integrated Extraction System (ARIES) Program Plan, Revision 1, Los Alamos National Laboratory document LA-UR-96-866 (February 2, 1996).

8. Advanced Recovery and Integrated Extraction System (ARIES) Technical Task Plans/Statements of Work for FY96, Los Alamos National Laboratory document (February 1996).

9. Timothy O. Nelson, M. C. Bronson, D. K. Dennison, Bart Flamm, Dewey Ravenscroft, Carlos Colmenares, John Huang, Terry Cremers, Thomas Sampson, Lawrence Bronisz, H. E. Martinez, Paul Sayka, Donald Pornplun, and Ralph Hinde, Advanced Recovery and Integrated Extraction System (ARIES) Preconceptual Design Report, Los Alamos National Laboratory report LA-13178 (September 1996).

10. Ralph F. Hinde, Jr., ARIES Instrumentation and Control System (ARIES ICS) Man-Machine Interface Design Standard, STD-ARIES-ESAEPE-0001, Rev. 0 (March 14, 1996).

11. Ralph F. Hinde, Jr., ARIES ICS Parameter Name Design Standard, STD-ARIES-ESAEPE0003, Rev. 0 (March 14, 1996).

12. Winslow Brough, Dewey Ravenscroft, and Wendel Brown, Addendum to the ARIES Integrated Test Plan, Lawrence Livermore National Laboratory document CLYA-96-0010 (August 21, 1996).

13. Winslow Brough, Modification to ARIES Integrated Test Plan, Lawrence Livermore National Laboratory letter CLYA-96-0012 to Nazir Kahlil, DOE/Albuquerque/WQD (September 13, 1996).

14. “ARIES Dismantling Reduces DOE's Plutonium Stockpile," Pollution Prevention Advisor 6:3, pages 1, 4 (Third Quarter 1996). 
15. "New Technologies Convert Fissile Materials for Indefinite Storage," Dateline: Los Alamos, November-December 1996, Los Alamos National Laboratory document LALP-96-1-11/12, pages 8-13 (1996).

16. Sigfried E. Hecker, The Los Alamos National Laboratory Annual Report to the Regents University of California, Los Alamos National Laboratory document LALP-95-245 (1995). 